\title{
Multimodal Hallucination (Audio-visual, Kinaesthetic and Scenic) Associated with the Use of Zolpidem
}

\author{
Dushad Ram¹, Najla Eiman', Basavana Gowdappa ${ }^{2}$ \\ Departments of ${ }^{1}$ Psychiatry and ${ }^{2}$ Medicine, JSS Medical College, Mysore, India
}

We are reporting a case of zolpidem induced multimodal hallucinations in a 22 year old female without any history of psychiatric disorders. Zolpidem, by acting on gamma-amino butyric acid type A receptor has a potential to cause a paradoxical reaction and there also exists a possibility of an induced delirium with its use. This case reports evaluates its potential to cause multimodal hallucinations. Zolpidem needs to be prescribed judiciously with the caution of potential side effects particularly in females.

KEY WORDS: Multimodal hallucinations; Zolpidem; Sleep initiation and maintenance disorders.

\section{INTRODUCTION}

Zolpidem (ZPD) selectively activates alpha 1 subunit of the omega-1 (BZ1) receptor of the gamma-amino butyric acid type $\mathrm{A}$ (GABA-A) which may account for its selective sedative effects and relative lack of muscle relaxant and anticonvulsant effects compared to benzodiazepines. ZPD may cause unusual perceptual experience (commonly visual and auditory) in person with history of mental illness and with or without associated distress and amnesia. ${ }^{1-4)}$ Here we are reporting a case of multimodal hallucination (audio, visual, kinaesthetic, and scenic) following the use of ZPD.

\section{CASE}

A 22 year old unmarried female, a third year medical student with nil significant family history and a well adjusted premorbid personality had been experiencing sleep onset insomnia for twenty days prior to her exams. She would not sleep till $1 \mathrm{AM}$ and would get up late in the morning. She bought over the counter medication tablet ZPD $10 \mathrm{mg}$ after having seen her consultant prescribe the same for insomnia. After consuming a $10 \mathrm{mg}$ tablet of

\footnotetext{
Received: December 22, 2014 / Revised: February 12, 2015

Accepted: February 13, 2015

Address for correspondence: Dushad Ram, MD

Department of Psychiatry, JSS Hospital, MG Road, Mysore, Karnataka 570004, India

Tel: +91-0821-2335501, Fax: +91-0821-2335187

E-mail: akashji1972@gmail.com
}

$\mathrm{ZPD}$, she sat on the floor mat along with another colleague of hers for studying till she felt sleepy. About 30 minutes later she complained to her friend that the letters appeared to be shaking and going out of order. She reported that words no longer stayed in a straight line but appeared in disarray. Few minutes later she raised her hand to alarm that she was about to sink. Following this she had a very weird experience.

She felt to be in a lake and surrounded by water; floating with her friend on a boat and her body was bouncing up and down and the surrounding had assumed a bright orange hue. She was very frightened, held her friend asking for help and requesting to park at lakeside.

They stopped studying and her friend tried to convince that no such thing is occurring, and took her to TV room. She reported that the characters are coming out of the TV (that was switched off) and she tried to approach them; was talking to them as if they were in their room and unable to delineate with her surroundings though she was oriented to time and to her friend. There was no report of unusual experience in touch, pain, temperature or other modality. The friend convinced her and took her to bed and she fell asleep after 10 minutes. The next morning she had memories of the same and could recollect the events and consulted the physician. On assessment there was no evidence of physical illness, other substance abuse, nightmare or night terror or any other psychiatric disorder or any other concomitant medication use. Assessment of causal association with World Health Organization probability scale and Naranjo's Algorithm (score $=8$ ) revealed a

(c) This is an Open-Access article distributed under the terms of the Creative Commons Attribution Non-Commercial License (http://creativecommons.org/licenses/by-nc/4.0) which permits unrestricted non-commercial use, distribution, and reproduction in any medium, provided the original work is properly cited. 
"probable" association of this adverse event with ZPD. ${ }^{5,6)}$ She was prescribed tablet nitrazepam $5 \mathrm{mg}$ at bedtime till her examination got over. Her sleep improved without any significant adverse event. After four weeks nitrazepam was tapered off over next two weeks. She was advised to avoid use of ZPD in future, practice sleep hygiene and relaxation techniques.

\section{DISCUSSION}

This case highlights serious side effect associated with use of ZPD in normal dose range. In this case clusters of symptoms that developed immediately after the use of ZPD raised few queries - whether it was a paradoxical reaction or delirium or whether it was just a multimodal hallucination.

Symptoms profile of this case has some similarity with paradoxical reaction such as increased anxiety level, hyperactivity etc. Also that ZPD is a potential substance for paradoxical reaction as it acts on GABA A receptor that is linked to such reaction. This possibility was excluded as patient did not complaint of anxiety or inability to stay at a place but rather it was a reaction to unusual experience. Delirium was also excluded because patient was oriented to time and person and because of unusual visual experience she had difficulty in ascertaining the place. Thus finally the event was considered as ZPD induced hallucination. In this case it is unique due to presence of multiple hallucinations (audio: hearing voice of TV character, visual: lake and boat, kinaesthetic: perception of body movement up and down, and scenic: seeing a TV show with lively characters) without amnesia and re-experience with nitrazepam.

Though there are case reports of visual distortion and hallucination, this case was interesting due to presence of multimodal hallucination. ${ }^{7)}$ Common clinical characteristics of the patients who reported such experience were mostly female, had mental illness, were on other psychotropic medication, doses of ZPD was $\geq 10 \mathrm{mg}$, onset of symptoms within 20-30 minutes after ingestion, improved without treatment after several hours of discontinuation. ${ }^{7)}$ Toner et ll. $^{8)}$ suggested ZPD concentration may be more in female, low serum albumin with inhibition of CYP3A4 isoenzyme and dose higher than $5 \mathrm{mg}$ may cause perceptual abnormality. It is speculated that in such phenomena GABA receptor ( $\alpha_{1}$ subunit) may be over-expressed or they may be rapid activation after quick absorption in sensitive individuals. ${ }^{9}$ GABA A $\alpha_{1}$ receptor constitutes a high proportion of GABA receptors and high concen- tration is present in limbic brain areas that has been associated with multimodal hallucination in neuroimging studies. ${ }^{10-12)}$ Reduced sleep latency with ZPD use has similarity with narcolepsy; a sleep disorder that is often associated with hallucination and dysfunction of GABAergic function is often speculated. There is a possibility that similar to other GABA A $\alpha_{1}$ agonist (e.g., muscimol) ZPD may also have hallucinogenic property. In few studies the GABA A $\alpha_{1}$ receptor agonist (e.g., muscimol) was found to increase the firing of dopaminergic neuron in the ventral tegmental area (origin of the mesolimbic and mesocortical tract) a neuroantomical structure known to be associated with psychotic symptoms in schizophrenia. ${ }^{4)}$

Contrary to the other report, in this case there was no amnesia for the event. Literature suggests that mood disorders, substance used disorders, concomitant medication or somatic comorbidities are significant factors in contributing to amnesia, and that were not present in this case. ${ }^{13)}$ Review suggests that patient who experience amnesia were on antidepressant that can attenuate GABAergic transmission facilitating neuronal activation and the release of dopamine that can contribute to unusual perceptual experience in individuals predisposed to decreased monoaminergic neurotransmission levels. ${ }^{13)}$

In this case patient did not re-experience the symptoms with the use of nitrazepam, probably due to non-selective receptor binding profile. In conclusion, although ZPD is believed to be safe it can have rare deleterious side effects and should be used at the lowest effective dose in females.

\section{REFERENCES}

1. Markowitz JS, Rames LJ, Reeves N, Thomas SG. Zolpidem and hallucinations. Ann Emerg Med 1997;29:300-301.

2. Elko CJ, Burgess JL, Robertson WO. Zolpidem-associated hallucinations and serotonin reuptake inhibition: a possible interaction. J Toxicol Clin Toxicol 1998;36:195-203.

3. Huang CL, Chang CJ, Hung CF, Lin HY. Zolpidem-induced distortion in visual perception. Ann Pharmacother 2003;37: 683-686.

4. Garbutt JC, van Kammen DP. The interaction between GABA and dopamine: implications for schizophrenia. Schizophr Bull 1983;9:336-353.

5. Naranjo CA, Busto U, Sellers EM, Sandor P, Ruiz I, Roberts EA, et al. A method for estimating the probability of adverse drug reactions. Clin Pharmacol Ther 1981,30:239-245.

6. World Health Organization. The use of the WHO-UMC system for standardised case causality assessment [cited 2014 Aug 24]. Available from: http://who-umc. org/Graphics/ 24734.pdf.

7. Inagaki $\mathrm{T}$, Miyaoka $\mathrm{T}$, Tsuji $\mathrm{S}$, Inami $\mathrm{Y}$, Nishida $\mathrm{A}$, Horiguchi J. Adverse reactions to zolpidem: case reports and a review of the literature. Prim Care Companion J Clin Psychiatry 2010;12. doi:10.4088/PCC.09r00849bro.

8. Toner LC, Tsambiras BM, Catalano G, Catalano MC, Cooper 
DS. Central nervous system side effects associated with zolpidem treatment. Clin Neuropharmacol 2000;23:54-58.

9. de Haas S, Dingemanse J, Hoever P, Cohen A, van Gerven J. Pseudohallucinations after zolpidem intake: a case report. J Clin Psychopharmacol 2007;27:728-730.

10. Pirker S, Schwarzer C, Wieselthaler A, Sieghart W, Sperk G. GABA(A) receptors: immunocytochemical distribution of 13 subunits in the adult rat brain. Neuroscience 2000;101: 815-850.
11. Young AB, Chu D. Distribution of GABA, and GABA, receptors in mammalian brain: potential targets for drug development. Drug Dev Res 1990;21:161-167.

12. Silbersweig DA, Stern E, Frith C, Cahill C, Holmes A, Grootoonk S, et al. A functional neuroanatomy of hallucinations in schizophrenia. Nature 1995;378:176-179.

13. Cubała WJ, Gabrielsson A. Sleep related amnestic behaviors due to zolpidem. Bull Clin Psychopharmacol 2014;24:188194. 